\title{
Right to dispose of your own life: actualization of social-political context in COVID-19 pandemic conditions
}

\author{
N. N. Tarusina ${ }^{1}$
}

${ }_{1}^{1}$ P. G. Demidov Yaroslavl State University, 14 Sovetskaya str., Yaroslavl 150003, Russian Federation

DOI: $10.18255 / 2412-6519-2021-2-166-181$

Research Article

Full text in Russian

The article examines the content of a person's right to dispose of his life (with emphasis on socio-political meanings) as a component of his right to life, including assumptions, probabilistic or unacceptable, about alternatives to the deployment of individual elements of this possibility (voluntary departure from life, the assumption of euthanasia, as well as options for the embodiment of the idea and the right to risk your life).The last one is analyzed both in a classical way (within the framework of activities objectively related to occupational risks and other activities with similar characteristics), and in an updated context due to the coronavirus pandemic. The author reflects on the socio-political, sociological and other aspects that have manifested or strengthened their presence in doctrine, public practice and public policy in connection with the current emergency situation, illustrates them with specific examples, examines and criticizes individual decisions on this issue, especially in relation to the elderly people, states in this regard the emergence in the Russian socio-political space of a new type of minorities subjected to discrimination. It is also compares the strategy and tactics of decision-making by power structures and major confessions during a pandemic, including for the elderly. Considerations are expressed about the need to take into account the experience of making political decisions in such situations, and to correct them on the base of state, social and individual interests and meanings.

Keywords: to be one's own master; pandemic; COVID-19; citizen; limitations of rights; discrimination; social-political context

INFORMATION ABOUT THE AUTHORS

Tarusina, Nadezhda N.

E-mail: nant@uniyar.ac.ru

ORCID 0000-0001-8827-5532

Cand. Sc. (Jurisprudence), Professor, Department head

For citation: Tarusina N. N. Right to dispose of your own life: actualization of social-political context in COVID-19 pandemic conditions // Social'nye i gumanitarnye znanija. 2021. Vol. 7, No 2. P. 166-181. (in Russ.) 


\title{
Право распоряжаться своей жизнью: актуализация социально-политического контекста в условиях пандемии COVID-19
}

\author{
Н. Н. Тарусина ${ }^{1}$
}

1Ярославский государственный университет им. П. Г. Демидова, ул. Советская, 14, Ярославль, 150003, Российская Федерация

DOI: $10.18255 / 2412-6519-2021-2-166-181$

УДК 323.2

Научная статья Полный текст на русском языке

В статье рассматриваются вопросы содержания права человека распоряжаться своей жизнью (с акцентами на социально-политические смыслы) как компонента его права на жизнь, включая предположения, вероятностные или же неприемлемые, об альтернативах развертывания отдельных элементов указанной возможности (добровольный уход из жизни, допущение эвтаназии, а также варианты воплощения идеи и права рисковать своей жизнью). Последнее анализируется как в классическом ключе (в рамках деятельности, объективно связанной с профессиональными рисками, и иных видов деятельности со сходными характеристиками), так и в актуализированном контексте, обусловленном коронавирусной пандемией. Автор размышляет о социально-политических, социологических и иных аспектах, проявившихся или усиливших свое присутствие в доктрине, общественной практике и государственной политике в связи с действующей чрезвычайной ситуацией, иллюстрирует их конкретными примерами, рассматривает и подвергает критике отдельные решения по данному вопросу, особенно в отношении пожилых людей, констатирует в этой связи появление в российском общественно-политическом пространстве нового вида меньшинств, подвергаемых дискриминации. Сравнивается также стратегия и тактика принятия решений властными структурами и основными конфессиями в период пандемии, в том числе в адрес пожилых людей. Высказываются соображения о необходимости учета опыта принятия политических решений в подобных ситуациях, их корректировки на основе учета государственных, общественных и индивидуальных смыслов и интересов.

Ключевые слова: распоряжаться своей судьбой; пандемия; коронавирус; гражданин; ограничения прав; дискриминация; социально-политический контекст

\section{ИНФОРМАЦИЯ ОБ АВТОРАХ}

Тарусина, Надежда Николаевна

E-mail: nant@uniyar.ac.ru ORCID 0000-0001-8827-5532

Кандидат юридических наук, профессор, завкафедрой

Для цитирования: Тарусина Н. Н. Право распоряжаться своей жизнью: актуализация социальнополитического контекста в условиях пандемии COVID-19 // Социальные и гуманитарные знания. 2021. Том 7, № 2. С. 166-181. 
Коронавирусная пандемия видоизменила многие, если не все, «смысложизненные» компоненты - от этико-философской, религиозной, психологической до правовой природы [1]. При этом очевидно, что беспрецедентные меры, принимаемые российским и другими государствами, в большой степени различно воспринимаются и внутри политической/правящей элиты, и в стратах гражданского общества, и конкретным человеком. Соответственно, в первом случае мы имеем решения как соразмерные, так и несоразмерные пандемическим и производным от него рискам, а во втором - исключительно дифференцированные реакции: от осознанного или вынужденного подчинения вводимым ограничениям до открытой или скрытой агрессии, ковид-диссидентства и безразличия. Государственные структуры разных стран «меряются силами» в вопросах борьбы с пандемией: объявляют страну «х» виновницей распространения вируса и немедленно уходят в «информационный песок», если появляются небезосновательные указания на вину совсем другого государства; устраивают гонки за вакциной (российская наука дожала этот интеллектуальный вес - и первая «порвала ленточку» в забеге); делятся или не делятся ресурсами с нуждающимися в помощи (перенаправляют в свое небо самолет с медицинскими масками; пытаются перекупить специалистов и целые фармкомпании); обливают информационными «помоями» конкурентную российскую вакцину, а затем отступают от прежней позиции - с неопределенным результатом; объявляют локдауны и закрывают целые города в квартирах; квалифицируют помощь российских военных медиков как бесполезную и пиарориентированную; жестко подавляют «ковидные» протесты (вплоть до применения сил конной полиции и кинологов) и ищут «соринку в российском политическом глазу», безмерно сожалея об отсутствии таковых протестов у нас и т. д. На этом фоне не получила международной поддержки идея российского президента о создании гуманитарных «зеленых коридоров», однако она была реализована и продолжает реализовываться на локальных уровнях - в виде медицинской (в том числе консультационной) помощи, предоставлении вакцины и прав на локализацию ее производства, а также медицинского оборудования, средств защиты ${ }^{1}$.

Среди большого числа политических, экономических и гуманитарных проблем, рожденных или актуализированных означенной чрезвычайной ситуацией, весьма значимое, если не одно из фундаментальных мест, занимают вопросы о содержательных компонентах права на жизнь как основного среди прав человека первого поколения. Ибо, собственно, о чем же ином и беспокоятся правящие элиты и рядовые граждане, как не об этом, - не на теоретическом уровне, а на уровне прикладном и лично ощущаемом. Тем не менее это не исключает и некоторой доктринальной отстраненности (в разумной, конечно, степени) от каждодневной повестки «ковидного дня», попытки встроить данную чрезвычайную проблематику в общий контекст конструкции прав и свобод человека и их обоснованных либо чрезмерных ограничений, ведомых разнообразно трактуемыми интересами публичного порядка.

\footnotetext{
${ }^{1}$ Политологи подчеркивают, что особенности национальной ментальности выявили два противоположных подхода к решению биополитических проблем, в частности, производных от обстоятельств пандемии: практики солидарности проявились в странах с доминирующими коллективистскими ценностями, а практики политического эгоизма - при доминировании индивидуалистских акцентов государственного поведения [2, с. 95].
} 
Так, право на жизнь изначально допускает весьма неоднозначные, неоднополярные трактовки - при решении вопросов о точке отсчета своего возникновения, соответственно, охране и защите, прерывании жизни проточеловека, наличии у него самоценностных интересов и их обеспечении институтами морали, политики, права, о мере вмешательства третьих лиц и государства в его реализацию и даже его отъем [3; 4]. Оставляя обсуждение данных проблемных аспектов другим авторам (не исключая, впрочем, и себя, но в ином временном и информационном пространстве), перейдем к не менее спорным позициям по более узкой заявленной теме.

Среди компонентов права на жизнь значимое место занимает правомочие распоряжаться своей жизнью. В доктрине выявлены три относительно самостоятельных элемента композиции означенного распоряжения: «право на самоубийство», право на эвтаназию и право рисковать своей жизнью. Политические и этические подходы к означенным вопросам имеют как общие, так и специфические характеристики. Это, как и должно, отражается в политических заявлениях и практиках, законодательстве, российском и зарубежном, различая их и векторно, и содержательно, как в связи с общей тенденцией к разнообразию национальных политических реалий, национального права, в том числе в области прав и свобод человека (при универсальности данной конструкции, впрочем, спорной), так и в связи с очевидной нетривиальностью указанных элементов. Первые два элемента, казалось бы, напрямую не связаны с пандемическим контекстом, однако мы считаем необходимым адресовать им несколько тезисов по трем причинам: без их характеристики «картина» права распоряжаться своей жизнью будет неполной, не отразит его содержания; бытийное воплощение этих специфических распоряжений в чрезвычайных ситуациях в том или ином виде может актуализироваться и видоизмениться; соответственно, не исключается и корректировка доктринальной и официальной их оценки в «постоковидный» период.

Так, «право на самоубийство», конечно же, в России и в абсолютном большинстве других государств не имеет официального признания (исключение составляют некоторые западные страны, о чем речь впереди, во взаимосвязи их законодательных решений об означенном праве и праве на эвтаназию). Не только регуляторных норм, но и охранительных, то есть ответственности за самоубийство, законодатель не устанавливает, так как отвечать, собственно, некому (кроме уголовного преследования другого лица за доведение до самоубийства - ст. 110 Уголовного кодекса РФ). Можно говорить лишь о некоторых регуляторах в этической и религиозной сферах: этика призывает к поиску нравственных образцов, гармонизации внутреннего мира, ответственности перед близкими. Церковь, осуждая эту акцию как греховную, осуществляет аналогичные призывы, дополненные известным адресатом, и одновременно вводит определенные обрядовые ограничения. Власти же озабочены агрессивностью информационного поля Интернета, призывающего к суициду, что, наконец-то, получило свое выражение в проектировании соответствующих ограничений и даже в практике блокировки сайтов.

Однако неблагоприятные юридические последствия все же установлены, но для особых случаев - для так называемых «неудачливых самоубийц»: в федеральном законе «0 психиатрической помощи и гарантиях прав граждан при ее оказании» (п. 4, ст. 24) предусмотрено, что психиатрическое освидетельствование может про- 
изводиться без согласия гражданина (принудительно) - при наличии непосредственной опасности для него самого (и окружающих). Насколько это гуманно и справедливо для всех случаев попытки самоубийства без исключения, непростой этический, психологический и юридический вопрос. И он все же решается, но не в жестко императивном ключе, а на диспозитивном уровне - врачом-психиатром с санкции судьи, то есть в рамках административного и судебного усмотрения, с учетом обстоятельств конкретной ситуации. Именно технология придания относительной неопределенности данной правовой норме позволяет принять адекватное, гуманитарное решение, если, конечно, к тому способны конкретные субъекты ее применения.

При этом очевидно, что медико-психологические и юридические средства не способны достигать приемлемого эффекта. Государственные институты пытаются выстраивать режимы превенции, консервативно-классические и осовремененные информационно-цифровым модерном, отставая, к сожалению, от проявлений его негативного воздействия, как, впрочем, и в других сферах частной, общественной и политической жизни. Значимую роль в деле превенции выполняют и должны выполнять некоммерческие организации социальной направленности, которые в последние годы расширяют сферу своих компетенций и оптимизируют результаты своей весьма полезной деятельности, в том числе на основе поддержки и координации со стороны соответствующих ресурсных центров ${ }^{1}$ [5]. Очевидно, что сплав политических ресурсов и ресурсов гражданского общества актуален и при решении данной проблемы.

Второй содержательный срез пространства права распоряжаться своей жизнью олицетворяет собой законную возможность прибегнуть к эвтаназии (от греческого - «хорошая смерть»). В научный обиход данный термин ввел Френсис Бэкон (в книге «0 достоинстве и приумножении наук» (1623 г.), который, в частности, отметил: «... обязанность врача состоит не только в том, чтобы восстановить здоровье, но и в том, чтобы облегчить страдания и мучение, причиняемое болезнью, и это не только тогда, когда такое облегчение боли как опасного симптома может привести к выздоровлению, но и в том случае, если уже нет ни единой надежды на спасение и можно лишь сделать саму смерть более легкой и спокойной, такая эвтаназия уже самая по себе есть немалое счастье» [6, с. 268]. Впоследствии данное понятие и действия, им обозначаемые, приобрели иной смысл: акцент с понимания эвтаназии как естественной безболезненной смерти был перенесен в область специального в нее вмешательства. В современном прочтении ее отличают следующие характеристики: активный или пассивный вид деятельности с участием профессионального субъекта - медицинского работника (врача, фельдшера, медсестры, медбрата), которая совершается сознательно и преднамеренно с явно выраженным предвидением последствий в виде смерти пациента и на основе осознанной и однозначно трактуемой просьбы последнего либо его законного представителя (если пациент не способен к волеизъявлению) с уведомлением того (или другого) о необратимости последствий [4, с. 89-90]. Пассивная эвтаназия предполагает неприменение средств и невыполнение необходимых медицинских манипуляций для поддержания жизнеспособности терминального больного. Активная же может проявлять себя в трех альтернативных ипостасях: в «убийстве из милосердия», «самоубийстве,

\footnotetext{
${ }^{1}$ Ярким примером такого помощника является АНО «Ресурсный центр поддержки некоммерческих организаций и гражданских инициатив», действующий в Ярославской области.
} 
ассистируемом врачом/иным медработником», «самоубийстве при попустительстве медицинского персонала» (когда пациенту оказывается доступно соответствующее техническое средство или препарат).

В настоящее время окончательное отношение к эвтаназии пока не сформировано. Философско-этический, медицинский и юридический дискурсы объединяются в дискурс социально-политический. Так, ее сторонники, утверждая, что эвтаназия de facto все равно существует и ее узаконение с необходимостью нормативно упорядочит то, что осуществляется на стихийно-инициативной основе, подчеркивают: 1) цель соответствующих действий заключается в помощи безнадежному больному избавиться от страданий, достойно уйти из жизни; 2) отказ медиков пациенту, испытывающему невыносимые страдания, может квалифицироваться как применение к человеку пыток, жестокого обращения 1 ; 3) человек имеет право на жизнь, включая свободу распоряжения данным правом по своему усмотрению; 4) такое решение расширяет завещательные и другие юридические возможности выражения воли осознанно и заранее; 5) эвтаназия избавляет членов семьи от тяжких моральных, физических и финансовых испытаний (которые могут длиться годами, ложиться тяжелым бременем и разрушать, иной раз невосполнимо, их собственное здоровье). При этом она предполагается возможной исключительно при наличии продолжительного заболевания и его лечения, максимального использования медицинских технологий для улучшения состояния больного и их исчерпания, неотвратимости летального исхода, крайне тяжелых страданий пациента, его осознанного добровольного решения, процессуальных гарантий - экспертизы заболевания и воли пациента, консилиума врачей, уведомления близких родственников, санкционирования эвтаназии судом или прокурором [4, с. 94-95].

Контраргументация противников эвтаназии также характеризуется разноплановостью и разновекторностью: при решении вопроса возможны врачебные ошибки и порок воли больного человека, измученного болью, даже если констатация терминального состояния и осознанное волеизъявление осуществлены консилиумно; узаконение данного вида деятельности может отрицательно повлиять на состояние общественной морали, а также спровоцировать злоупотребления в области медицинской науки и практической медицины - приостановить ее развитие в направлении поиска новых методов лечения, массовое применение (в том числе по кадровым и финансовым соображениям), следует также учитывать восприятие эвтаназии религиозными конфессиями, оказывающими влияние на большие группы верующих или внешне к ним примыкающих.

\footnotetext{
'Элементы «медицинского жестокосердия» (при всем уважении к профессии и их носителям), к сожалению, встречаются в самых различных областях, а в недавней истории - особенно, например, отказ от применения наркоза при прерывании беременности (с профилактическо-воспитательной целью? ...) или при удалении зубного нерва (с целью заботы о здоровье пациента, ибо обезболивающие препараты вредны? ...) и т. п. Возникает житейская потребность задать вопрос: в отношении себя и своих коллег поступали аналогичным образом? ...
} 
Так или иначе, философско-этическое обоснование запрета последней на политическом уровне принимается большинством европейских стран ${ }^{1}$ и странами Востока. Однако есть государства, которые все же идут по другому пути. Так, в Нидерландах в 2002 г. принят закон «0 прекращении жизни по желанию или помощь в самоубийстве», допускающий ассистированный суицид и эвтаназию (с 16 лет - на основе самостоятельного определения порядка и способа завершения своей жизни, а с 12 лет - с согласия родителей или иных законных представителей); аналогичные возможности предусмотрены в Бельгии (с 18-летнего возраста); имеются сходные судебные прецеденты в ряде штатов США (а, например, в Калифорнии действует закон 1997 г. «0 праве человека на смерть»; пассивная эвтаназия разрешена в Японии, Колумбии и др. [4, с. 100-101]. В России же в федеральном законе «Об основах охраны здоровья граждан в Российской Федерации» предусмотрен прямой ее запрет (ст. 45). В доктрине высказано также пожелание к законодателю квалифицировать данную деятельность не в рамках норм ст. 106 Уголовного кодекса РФ (убийство, с применением конструкции смягчающих обстоятельств - из сострадания), а на основе специального состава, однако подобное предложение вызывает и возражения, так как привилегированный состав может провоцировать злоупотребления со стороны родственников и медработников. В соответствии с Венецианской декларацией о терминальном состоянии (1983 г.), «отказ от лечения не освобождает врача от обязанности помочь умирающему, назначив лекарства, облегчающие страдания»; в Декларации об эвтаназии 1987 г. подчеркивается: данная деятельность неэтична, но это «не исключает необходимости уважительного отношения врача к желанию больного не препятствовать течению естественного процесса умирания в терминальной фазе заболевания». Медицинская, правовая и политическая доктрины большинства европейских стран исходят из идеи приоритетного развития не эвтаназии, а паллиативной помощи, устранения боли и поддержки терминального больного и членов его семьи. Нормы ст. 36 указанного ранее российского закона (в редакции 2019 г.) также ориентированы именно на это, однако очевидно, что нормотворчество в этой области - дело необходимое, но далеко не достаточное: без обеспечения организаций паллиативной помощи квалифицированными кадрами, добровольческой поддержкой и благотворительностью правовые нормы обречены на бесплодие 2 . В этом вопросе, как и во многих других (см. тезисы о превенции самоубийств), некоммерческие организации социальной направленности незаменимы. А российское государство незаменимо в вопросе их системной и одновременно адресной поддержки - политической и экономической [7, с. 10-13].

Третий компонент права распоряжаться своей жизнью, в том числе рисковать ею, представлен в доктрине, законодательстве и общественной практике в весьма разнообразных и вполне актуальных проявлениях. Как таковое право рисковать

\footnotetext{
'Это, конечно, в настоящее время не может, в принципе, являться ключевым, решающим аргументом (только на основании его высказанности западным миром) - как в связи с относительной, а не абсолютной, универсальностью конструкции прав и свобод человека, так и в связи с конкретными образцами их европейского прочтения (например, законодательного закрепления и идеологического продвижения идеи однополого брака, семьи на основе однополого или гендерно еще более нестандартного родительства и т. п.).

${ }^{2}$ Преподаватели, сотрудники и студенты юридического факультета ЯрГУ им. П. Г. Демидова в течение последних лет участвуют, совместно с прихожанами Троицкого храма (с. Введенье), в оказании поддержки паллиативным больным Ярославской районной больницы (приобретают продукты и предметы быта, выступают перед больными с концертными программами - исполняют прекрасные русские и российские песни...).
} 
своей жизнью, конечно же, не закреплено в законе, по крайней мере, российском, это имело бы слишком далеко идущие социально-политические, этические и психологические последствия. Но реализация возможности подобного риска прямо и не запрещена. Иначе было бы невозможно осуществлять профессиональную деятельность специального типа, самым непосредственным образом связанную с опасностью для жизни: обеспечение обороноспособности страны и ее правопорядка, спасательные работы в различных чрезвычайных ситуациях, личное участие в испытании технических средств (летающих, плавающих, едущих...), управление источниками повышенной опасности (от автомобилей до космических кораблей и мирного атома), добыча некоторых ресурсов (особенно подземных), научно-исследовательские работы (в области вулканологии, гидрологии, химии, фармакологии и пр.), участие в различных экспериментах (например, медицинских - в клинических испытаниях вакцины и т.п.). Разумеется, риски во всех этих случаях минимизируются или хотя бы частично уменьшаются постоянно совершенствующими правилами безопасности. Однако риски остаются, и граждане, включающиеся в такие виды профессиональной деятельности, осознанно принимают их на себя.

На второй (нижней) ступени по степени обоснованности рисков для жизни находятся те виды деятельности, которые не обусловлены явной (объективной) необходимостью самого своего существования: экстремальные виды спорта или иного «развлечения» - альпинизм, хай-дайвинг, авто/мотогонки, спортивные прыжки с парашютом; цирковая акробатика, любительская охота, зимняя рыбалка и пр. Разумеется, и в этом специфическом пространстве жизни имеются комплексные регуляторы, направленные на умаление опасности, что, впрочем, далеко не всегда оправдывает само существование того или иного вида любительских рисков. С другой стороны, «преодоление себя» может оказываться способом решения значимых жизненных проблем, способом существования/достойного выживания (например, для людей с инвалидностью ${ }^{1}$ ). А значит, и в этом направлении необходимость социально-политической поддержки государства просматривается «невооруженным глазом».

В 2020-м году актуализировались проблемы, связанные с правом рисковать собственным здоровьем, в том числе в период пандемии. Появилось движение диссидентов, хотя и неоднородное: из любителей общественных протестов как таковых (и даже провокаторов), из неверующих в опасность ковида-19, из числа правозащитников, а также специалистов, оценивающих риски данного заболевания как не заслуживающие жестких и масштабных мер, принимаемых органами государственной власти и управления. Возникла и эволюционирует дискуссия в доктрине, в том числе политической и юридической, об основаниях ограничений и запретов и их соразмерности [8; 9], ибо оная соразмерность является одним из конституционно-правовых критериев ограничения прав и свобод: «... только в той мере, в какой это необходимо ...» (ч. 3 ст. 55 Конституции РФ).

\footnotetext{
${ }^{1}$ Одним из самых ярких и убедительных образцов подобного рода является паралимпийское движение. Невероятные по своей эмоциональной силе его образцы явились основой для появления и развития сходных инициатив, которые начинают получать не только общественную, но и государственную поддержку. (В 2020 г. вершина Эльбруса впервые покорилась человеку с инвалидностью, который в 2015 г. лишился ног в результате обрушения здания. Без финансовой и технической помощи восхождение не свершилось бы...)
} 
Однако, в отличие от восхождения на Эльбрус и иных образцов рискованной (любительской) деятельности, которые не носят массового характера, любые пандемии представляют опасность для весьма значительного числа людей, создают организационные трудности по обеспечению медицинской помощью тех, кто не хочет рисковать своей жизнью (не хватает мест в больницах, медицинского оборудования, лекарств, врачей, вспомогательного медицинского и технического персонала и т. д.). Таких людей - абсолютное большинство. Следовательно, вводимые государствами, в том числе российским, разнообразные и довольно жесткие ограничения свободы передвижения, вплоть до карантина, свободы труда, собраний, обычного человеческого общения (которое, по мысли А.П. Чехова, является непреходящей «роскошью») могут быть оправданы и легитимированы нормами ст. 55 Конституции РФ о праве политической власти вводить таковые ограничения в целях защиты здоровья самих граждан, прав и законных интересов третьих лиц и безопасности государства. В этом смысле не только требования самоизоляции, специального режима передвижения, перевода на удаленную форму работы и учебы, но и требование обязательного ношения масок (перчаток?), пользования санитайзерами, соблюдения безопасной дистанции в общественных местах являются конкретизаторами означенных конституционных положений.

С очевидностью следует заметить, что ни политически, ни психологически, ни организационно и ни юридически мы не были к данной чрезвычайной ситуации готовы в необходимой мере, как, впрочем, и другие государства. Это, разумеется, является не основанием для полного оправдания оной неготовности, а лишь констатацией факта.

Если обратиться к анализу применяемого федерального и регионального законодательства, то, наряду с предоставлением льгот и послаблений (материальная помощь семьям с детьми, обеспечение бесплатными лекарствами, льготные кредиты, налоговые каникулы, технология «кэшбэка» в туристической отрасли, иные формы поддержки предпринимательства; льготы медицинским работникам, участвующим в лечении больных коронавирусной инфекцией; поощрение волонтерского движения и адресной благотворительности и т. д.), немалое число нормативных положений и практик вызывает вопросы, социальное и юридическое неудовольствие, неудовлетворение или даже протест.

Так, во-первых, в России использованы технологии неопределенного режима повышенной готовности и более определенного режима чрезвычайной ситуации не объявлено, в отличие от ряда стран, чрезвычайное положение, хотя ряд принимаемых мер (ограничений и запретов), скорее, характеризует именно его. Многие юристы объясняют это простой меркантильностью государства: норма ст. 27 федерального конституционного закона «О чрезвычайном положении» предусматривает право граждан на возмещение ущерба, а большого числа судебных исков, конечно, не хочется, так как они могут привести к значительным финансовым затратам - плюсом к тем, которые осуществляются и еще будут осуществляться в рамках регулятивной, а не охранительной функции государства. Правда, некоторые политологи и юристы все же полагают, что дело не только в этом, но также и в сущности чрезвычайного положения: «коронпандемия» пока до этой сущности не дотягивает (недаром в январе 2021 г. и в последующее время Правительство РФ, мэрия г. Москвы, руководство ряда регионов подчеркивают, что локдауны, комендантский час, всеобщий карантин и т. п. меры (в отличие от ряда стран) применять 
не планируется. Конечно, в этом подходе содержатся политический, экономический и социально-психологический компоненты, как следствие - аккуратные реакции власти на запросы граждан и российского общества в целом. Наличествует и потребность российской государственности продемонстрировать в условиях известного противостояния образцы своей успешности.

Во-вторых, четкие пределы ограничений прав граждан, в том числе в рамках региональных полномочий, на федеральном уровне установлены не были. Соответственно, губернаторы не только стали применять чрезвычайные меры еще до внесения соответствующих дополнений в федеральное законодательство, но и изобретали их «на ходу»: запреты или ограничения на въезд в регион, требование самоизоляции для всех граждан, для отдельных категорий (60 лет, 65 плюс), запреты прогулок, закрытие большинства учреждений и организаций и т. д. Мотивы подобных действий и различий в их региональных наборах не всегда были обусловлены эпидемиологической ситуацией: например, тотальная самоизоляция не вводилась в Тульской, Тверской, Ярославской и других областях, отличавшихся между собой по указанным показателям, и вводилась в Чеченской республике, на тот момент с более низкими характеристиками заболеваемости (впрочем, причины такового различия в данном случае вполне просматриваются - и они несоизмеримо ближе к политике и /или национально-культурному коду, нежели к медицине). Цифровой контроль исполнения введенных ограничений передвижения и самоизоляции также в большинстве регионов не осуществлялся (возможно, из-за его затратности, а возможно, и из опасения протестных акций, вероятность и массовость которых территориально различна) ${ }^{1}$. В целом контроль исполнения региональных указов и постановлений традиционно организовывался бессистемно (за редким исключением). И это, как всегда, явилось своеобразным «психологическим лекарством» для граждан: разрешение выходить из самоизоляции в ближайший магазин ${ }^{2}$, для выноса мусора или выгула собак выглядело (и на момент написания статьи выглядит) весьма экзотично, если использовать мягкие, литературные выражения. Да и сам термин «самоизоляция» звучит угрожающе и угнетающе действует на человеческую психику - его еще предстоит доктринально осмыслить психологам, социологам, юристам и представителям других профессий. Конечно, ошибки, переборы и даже откровенные конфузы ${ }^{3}$ и пр. можно объяснить (и они объясняются), как мы уже ранее отметили, чрезвычайной неожиданностью и сложностью возникших проблем и управленческих задач. Но и исключить справедливые упреки в адрес государственных структур также нельзя.

Совершенно отдельно от общей проблематики отстоит вопрос об ограничениях, введенных для граждан возрастной категории «65 плюс». Известные решения, по сути, создавали и продолжают создавать новый вид дискриминации, новую

\footnotetext{
${ }^{1}$ Ярославская область в этом отношении традиционно активна [10].

2 Это изобретение коронавирусной поры даже вызывает удивление. К тому же, например, в центре г. Ярославля число приемлемых по ассортименту и качеству продовольственных магазинов не удовлетворяет означенным требованиям. При этом граждане могут находиться на диете по заболеванию и нуждаться в продуктах, которые можно приобрести далеко не в ближайшей торговой точке.

${ }^{3}$ В мае 2020 г. в ситуации постепенного выхода из режима самоизоляции мэрией г. Москвы было принято неожиданное и странное решение: жителям разрешили выходить на прогулки по очереди: домам с четными номерами - по четным дням, с нечетными - по нечетным.
} 
группу «меньшинств». С одной стороны, обоснование их специального «пандемического статуса» зиждется на объективных факторах: существенно более высокий риск заражения коронавирусом, сопряжение его с хроническими заболеваниями пожилых людей, ослабленным иммунитетом и т. п. Однако, с другой стороны, только лишь заботой государства о своих пожилых гражданах все ограничения в их адрес объяснить нельзя: в их основу были положены и соображения о количестве «койкомест», и боязнь грядущей статистики смертности перед «мировым сообществом», и надежда на исполнительность этой возрастной категории, сформировавшуюся еще в нелегкое советское время, в том числе и предположение об относительно невысоком уровне гражданской активности данной возрастной группы (в отличие от 35-40-летних, а тем более - представителей юного возраста ${ }^{1}$ ). При этом власть отдавала себе отчет в том, что режим самоизоляции крайне вреден для физического и психического здоровья именно в означенном возрастном диапазоне (65 плюс и далее бесконечность). Кроме того, не было осуществлено явственной дифференциации между работающими и неработающими гражданами (пенсионерами) - нормативные исключения для категории 65 плюс, чей труд необходим для функционирования организации, появились в основном осенью 2020 г., их применение, разумеется, было адресовано руководителям в рамках административного усмотрения ${ }^{2}$, которое, как известно, весьма широко и субъектно разнообразно 3.

Таким образом, как мы уже отметили ранее, можно констатировать появление в социально-политическом пространстве нового вида меньшинств. При этом в доктрине выделяются количественные и качественные характеристики групп означенного типа [11, с. 123-124]. И хотя эти характеристики не универсальны, для группы пожилых людей они работают: 1) по состоянию на 01.01.2020 г. граждане 65 лет и старше составляют 15,47 \% от общей численности населения России, из них женщин - 66,69 \%, мужчин - 33,31 \%; 2) их объединяет критерий возраста. Другое дело, что в новейшее время те или иные меньшинства являются, по общему

\footnotetext{
${ }^{1}$ Небесспорное предположение, так как молодые люди, «вооруженные Интернетом», более приспособлены к домашнему режиму.

${ }^{2}$ В качестве примера «особой заботы» можно привести решение администрации вуза «х», коим преподаватели рассматриваемой категории переводились в режим работы online (в противовес более молодым) - с подчинением распоряжению об обязательном размещении лекционных и других учебных материалов в электронной образовательной среде. Возникал логичный вопрос: чем в этом смысле отличаются лекции и практические занятия в таком режиме от режима обычного?... А ведь это дополнительное требование удваивало объем работы (что, видимо, и свидетельствовало об особой заботе о немолодых профессорах и доцентах, традиционно, кстати, являющихся опорой любого вуза). С опозданием также последовали попытки материально-технического обеспечения дистанционного режима.

В мае по центральным каналам также сообщалось (для москвичей), что граждане 65 плюс имеют право в порядке исключения из режима самоизоляции выехать на дачу - «в один конец»... Реагировать на подобные оговорки, разумеется, следовало и следует на основе включения всех ресурсов иронии и самоиронии. Благо, как показала общественная практика эпохи «ковида», у россиян этих ресурсов - в избытке.

${ }^{3}$ Следует также иметь в виду, что миру и нашей стране известно немало политических и общественных деятелей, которым глубоко за 70. Поскольку они режиму самоизоляции, как правило, не подвергались, это усиливает дискриминационные контексты внутри указанной возрастной группы.
} 
правилу, субъектами специально охраняемого статуса и льготирования ${ }^{1}$, а рассматриваемая группа в «пандемическом» контексте подвержена дискриминации (или так называемой «позитивной дискриминации») - своеобразному «принудительному осчастливливанию». Следует также заметить, что в социологии задолго до означенных событий, но применительно к группе пожилых людей возникла даже тема «геронтологического эйджизма» - комплекса дискриминирующих практик и установок в отношении граждан старших возрастов. Между тем, как показывают результаты соответствующих новейших исследований, излишний патернализм отнюдь не всегда способствует сохранению данной «возрастной популяции», напротив, он снижает энергетический и интеллектуальный потенциал пожилых людей, ослабляет их сопротивляемость возрасту и даже усугубляет индифферентность к жизни - вместо поощрения к более точной самооценке возможностей и формирования добровольного и разумного самоограничения, самоосознанного, а не принудительного [13]. При этом вред от режима принудительной самоизоляции также вполне очевиден, как для психического, так и для физического здоровья именно и прежде всего людей в возрасте 65 плюс.

Полагаем, что пожилых людей нельзя считать «пешками в большой игре»², выделять их в особым образом дискриминируемую группу - следовало бы применить к ним не технологию жесткого запрета, а диспозитивную методику «мягкого права»: ознакомить их с неблагоприятной статистикой и основанных на ней рекомендациях медиков, предложить несколько «пряников» в виде ухода на больничный, материальной поддержки избравших «путь самоизоляции», системной и понятной волонтерской помощи, первоочередной вакцинации, бесплатного тестирования на ковид/антитела, демонстрации грамотных телепрограмм о рисках для данного возраста и т. д. (возможно, и в сочетании с «кнутом», например, отменой льготного проезда, как это было сделано в Москве, и др.). Необходимо также мотивировать солидаризацию различных групп российского общества, их установку на взаимопомощь и сплоченность перед бедой [14], аккуратно избегая избыточной акцентации на группы риска.

В этом плане далеко не бесполезно обратиться к практике «мягкого нормирования» поведения граждан в столь непростой период нашего бытия со стороны основных конфессий. Так, с одной стороны, в самом начале «пандемического цикла» патриарх Кирилл в своем обращении к верующим подтвердил необходимость самоизоляции и благословил их на «подвиг неотлучного пребывания в своих жилищах». В доктрине это было квалифицировано как акт социальной солидарности, при том, что «осознание ценности человеческой жизни является неотъемлемой частью христианского богословия» и первичным источником концепции прав человека [15, с. 551]. С другой стороны, проявилось и «диссидентское начало»: верующие, призванные патриархом к законопослушанию и на этом основании к ограничениям

\footnotetext{
${ }^{1}$ За некоторыми исключениями (традиционными, например, неизжитые элементы дискриминации в отношении женщин; нетрадиционными - в отношении претензий не только на формальное равенство, но даже преимущества лГБТ-сообщества; и т. п.) [12].

${ }^{2}$ Среди них немало не только политических и общественных деятелей, но и академиков, профессоров, изобретателей технических устройств и вакцины, талантливых музыкантов и др. Но даже если и не опираться на «цвет серебряного возраста», то и в общей массе пожилых людей большинство разумно и ответственно относится к ценности человеческой жизни.
} 
своих канонических прав, все же принимали решения самостоятельно, в зависимости от собственного религиозного самоощущения, ибо значительная часть канонов составляет «существо и смысл церковной жизни» [Там же. С. 556]. Исламские религиозные деятели также поддержали ограничительные меры российского государства. Причем, как отмечают политологи, в отличие от православия, в среде муфтиев и мусульман в целом «ковидного диссиденства» почти не было замечено - большинство из них с пониманием приняли решения об ограничениях религиозной обрядности [16, с. 569-570]. Таким образом, в рассматриваемых видах религиозного пространства была достигнута относительная «симфония» между свободой вероисповедания, толкованием политических решений со стороны религиозных лидеров и решениями верующих о самоограничении.

Актуализируется также проблематика вокруг такой своеобразной конструкции, как «обязанность гражданина сохранять свое здоровье», корректировки ее содержания и взаимодействия отдельных элементов, как в контексте заботы о здоровье в период эпидемии/пандемии, так и в общесоциальном контексте. Конструкция была введена в юридический оборот именно действующим федеральным законом «Об основах охраны здоровья граждан в Российской Федерации» (в обороте политическом она возникла существенно раньше ${ }^{1}$ ). Однако, во-первых, конкретизация данной обязанности осуществлена только для отдельных случаев: обязательность прохождения медосмотров, если они предусмотрены законодательством для той или иной профессии, и соблюдения режима лечения в период временной нетрудоспособности, а также правил поведения пациента в медицинской организации. Во-вторых, не только не установлена (и объективно не может быть установлена ввиду явной неопределенности содержания) ответственность за неисполнение обязанности заботиться о сохранении своего здоровья в общем виде, но и далеко не исчерпывающе и явственно определены меры воздействия на гражданина в означенных конкретных случаях. В стратегическом контексте рассматриваемая обязанность - скорее социально-политическая, нежели юридическая конструкция. Соответственно, и технологии ее продвижения, закрепления в общественном и индивидуальном сознании и социальных практиках должны быть скорее политологическими, нежели формально-юридическими (за исключением конкретных предписаний для строго определенных типов ситуаций).

Апологетика общерегулятивного смысла рассматриваемой обязанности может вести не только к абсурдным, ввиду невозможности их индивидуализировать, требованиям (правильно питаться, не курить, не употреблять алкоголь, смотреть под ноги во время гололеда, делать утреннюю зарядку, выключать телевизор и гаджеты за час до сна, принимать витамины и средства профилактики против гриппа и т. п.), но и к опасности - в смысле трактовки обязанностей врача и медицинской организации обеспечивать надлежащее лечение (огрехи последних могут трактоваться как последствия несоблюдения приведенного перечня действий гражда-

\footnotetext{
${ }^{1}$ Развитие медицинской диагностики, биотехнологий и территориальная концентрация населения, как отмечается в доктрине, привело к всплеску социальной девиации (в смысле здоровья) и формированию потребности распространить биополитику на максимально возможное количество граждан, а это, в свою очередь, способствовало формированию «культуры опасности» и на ее основе - двух целей государства в рассматриваемой сфере: «1) воздействовать на тело больного, ... побуждая его к самодисциплине и к возвращению в «норму»; 2) организовать тотальный контроль за «социальным телом» всего населения» [2, с. 92].
} 
нина), а также их избыточных прав вмешиваться в его частную жизнь [17, с. 82]. Следует также иметь в виду, что данная общерегулятивная обязанность вступает в противоречие с профессиональными обязанностями весьма многочисленных категорий граждан, чья деятельность связана с риском, а также тех граждан, которые занимаются экстремальными видами спорта, туризма и т. д. Таким образом, декларированная норма п. 1 ст. 27 в значительной мере является благим пожеланием законодателя.

Что касается конкретных вариантов ответственности либо применения иных мер воздействия, то они развиты далеко не в равной степени. Так, непрохождение медицинского профосмотра может (и, видимо, должно) вести к отказу либо в приеме на работу, либо в продлении трудового договора. Однако реализация данного правила изобилует огрехами. Во-первых, организация (бюджетного типа, например, вуз) в полном объеме для этой цели не финансируется, значит, приходится искать компромиссные варианты: жестко требовать прохождения ежегодного медосмотра преподавателями, оформляемыми на основах внутреннего совместительства (по основной должности они могут быть избраны по конкурсу на 3-5 лет), а также искать для данной цели медицинскую организацию с демпинговыми ценами за услуги, что снижает их качество и наносит соответствующий моральный и психологический ущерб работникам (стояние в очередях, формальность осмотра, неумелость процедурной медсестры и т. п.). В период коронавирусной пандемии это особенно опасно (тем более что исключений для 65 плюс не делается ${ }^{1}$ ). Во-вторых, если вдумчиво проанализировать перечень медицинских услуг, то становится ясным, что он сформирован в значительной мере формально: например, неясно, зачем преподавателю вуза получать «одобрение» стоматолога и даже офтальмолога (право преподавания не исключено даже для незрячих ${ }^{2}$ и уж тем более - для лиц с зубными протезами, кариесом или пародонтозом); для онкологических же больных явно далеко не безвредной является ежегодная флюорография..

Конечно, в период пандемии конструкция рассматриваемой обязанности активно усиливается административной ответственностью за нарушение правил карантина, непредставление теста на коронавирус гражданами, прибывшими из-за границы (если такое правило установлено), и за иные действия. Полагаем, что данная подотрасль административного законодательства, получив необходимый импульс в чрезвычайных обстоятельствах, отныне будет только развиваться, а применение ее норм - находиться под разумным контролем госструктур 3 .

Таким образом, социальные и гуманитарные науки получили и продолжают получать чрезвычайно интересный материал для анализа и размышлений, политическая практика - для формирования «банка» управленческих решений, а практика законотворческая - для развития специализированного «антивирусного» законодательства, федерального, регионального и локального. Рассматриваемые чрезвычай-

\footnotetext{
${ }^{1}$ В этом в очередной раз ярко проявляется «забота» государства о пожилых людях: сочетание требования самоизоляции и обязательности прохождения медосмотра - результат своеобразной управленческой "логики», а скорее, отсутствия действительного системного подхода к вопросу. При этом об автомобилистах российские власти озаботились: были пролонгированы сроки действия водительских удостоверений.

${ }^{2}$ На юридических факультетах есть незрячие зав. кафедрами, профессора и т. д.

${ }^{3}$ Так, например, мэрия г. Москвы сообщила, что в несанкционированных публичных акциях 23 января 2021 г. приняли участи 19 человек, находящихся на карантине в связи с заболеванием ковидом.
} 
ные обстоятельства также значительно актуализировали и оживили дискурс относительно социально-политического и формально-юридического содержания права человека на жизнь, распоряжения ею по своему усмотрению, содержания и пределов ограничения прав и свобод человека в период нестандартных ситуаций, поиска разумного взаимодействия частных и публичных начал, интересов отдельной личности, групп граждан и политических структур. Указанные обстоятельства усилили и вектор размышлений политологов (в меньшей степени - правоведов, ибо юриспруденция есть концентрированное выражение политики) в сторону проблематики меняющейся роли государства в активно меняющемся мире, в том числе в контексте и в период так называемого «отложенного времени» [18, с. 195], государства социальной направленности [19; 20; 21], к которому, смеем надеяться, не только причисляет себя наша страна, опирающаяся отныне на известные конституционные поправки ${ }^{1}$, но и действительно активно этого желает. Методология политики, включая воздействие и на предмет нашего размышления, воистину должна стремиться к «симфонии» государственной безопасности, общественных и индивидуальных смыслов и интересов.

\section{Ссылки / References}

1. Озеров А. А. Смысложизненный компонент российского социума в условиях пандемии Covid-19 // Власть. 2020. № 6. С. 67-71.

2. Кравченко С. А. Пандемия Covid-19: вызовы здоровью населения мира - возможна ли гуманистическая глоболокальная биополитка? // Политические исследования. 2020. № 6. С. 91-102.

3. Резник Е. С. Право на жизнь: гражданско-правовые аспекты. М.: Юрлитинформ, 2010. $184 \mathrm{c}$.

4. Биомедицинское право в России и за рубежом / Г. Б. Романовский, Н. Н. Тарусина и др. М.: Проспект, 2019. 368 с.

5. Соколов А. В. Особенности деятельности НКО в условиях развития Интернета // Социальные коммуникации: наука, образование, профессия. 2020. № 20. С. 324-331.

6. Бэкон Ф. О достоинстве и приумножении наук // Сочинения в 2-х томах. Т. 1. М.: Мысль, $1971.590 \mathrm{c}$.

7. Головин Ю. А., Петрова О. В. Роль коммуникации в политико-административном управлении национальными проектами в Ярославской области // Социальные и гуманитарные знания. 2021. Том 7. № 1 (25). С. 6-17.

8. Филиппова С. Ю. Коронавирус ушел. Как нам теперь вернуть право? // Закон. 2020. № 5. C. 42-52.

9. Агальцова М. В., Иманова Т. В. Самоизоляция: анализ законности и конституционности антивирусных мер // Закон. 2020. № 5. С. 60-70.

\footnotetext{
${ }^{1}$ То, что они были осуществлены в период пандемии, еще долго будет обсуждаться в российском обществе (особенно в его либеральных кругах), но факт состоялся - и за ним должны последовать соответствующие доказательственные факты реальности поставленных задач.
} 
10. Соколов А. В., Палатников Д. Е. Протестная активность: опыт индексного анализа // Социальные и гуманитарные знания. 2018. № 4. С. 29-37.

11. Дехканов С. А. Международно-правовые критерии меньшинств // Вестник РУдН. Серия: Юридические науки. 2010. № 3. С. 122-131.

12. Tarusina N., Isaeva E. Equalization of legal status with respect to gender // Russian law journal. Vol. 4. № 3. P. 74-93.

13. Колпина Л. В., Реутов Е. В. Влияние эйджистских стереотипов на формирование самоограничительных практик старшего поколения // Среднерусский вестник общественных наук. 2019. Т. 14. № 2. С. 32-45.

14. Киселев И. Ю., Смирнова А. Г., Зуева С. В. Новый образ жизни в условиях социальной разобщенности: о солидарности на национальном и международном уровне // Общество в условиях социального разобщения: новые практики в образовании, бизнесе, коммуникациях и потреблении. Материалы междунар. научно-практич. конференции. Ярославль, 2021. С. 16-25.

15. Лункин Р. Н. Социально-политические последствия пандемии для Русской православной церкви: раскрытие внутреннего потенциала гражданской активности и социального служения // Вестник РУдН. Серия: Политология. 2020. Т. 22. № 4. C. 547-558.

16. Почта Ю. М. Государственно-конфессиональные отношения в России в условиях пандемии: вызовы и ответы // Вестник РУДН. Серия: Политология. 2020. Т. 22. № 4. C. 559-578.

17. Шишков С. Н., Полубинская Д. Е. Забота о сохранении здоровья как юридическая обязанность // Государство и право. 2020. № 10. С. 81-89.

18. Титова Л. Г. Российский политический процесс - отложенное время? // Социальные и гуманитарные знания. 2019. Том 5. № 3. С. 193-199.

19. Пушков А. В каком мире мы проснемся завтра // Российская газета. 13 мая 2020 г. № 100 (8154). C. 10.

20. Наумкин В. В. Модель не-Запада: существует ли государство-цивилизация? // Политические исследования. 2020. № 4. С. 78-93.

21. Петухов Р. В. Запрос на перемены: политико-ценностное измерение // Политические исследования. 2020. № 6. С. 103-118. 